\title{
IMPLEMENTASI PELAPORAN KEUANGAN BERKELANJUTAN (SUSTAINABLE FINANCE) DI PT. BANK NEGARA INDONESIA, TBK TAHUN 2015 - 2017
}

\author{
Saur Costanius Simamora \\ Dosen Tetap Prodi Manajemen Unsurya \\ saur@universitassuryadarma.ac.id
}

\begin{abstract}
ABSTRAK
Tujuan dari penelitian ini adalah mengetahui kinerja keuangan berkelanjutan (sustainable finance) pada PT. Bank Negara Indonesia, Tbk dengan tahun periode 20152017 yang meliputi aspek ekonomi, aspek lingkungan dan aspek sosial. Berdasarkan hasil aspek ekonomi, indikator meliputi jumlah kantor bank dalam negeri, kantor cabang luar negeri, jumlah akun consumer funding dan lending (termasuk kartu kredit), jumlah pinjaman, jumlah pendapatan, laba tahun berjalan, dividen, penyaluran program kemitraan dan penyaluran bina lingkungan. Indikator aspek lingkungan, meliputi penggunaan listrik, air, jumlah hutan/taman Kota BNI, luas hutan/taman Kota BNI, jumlah total pohon yang ditanam (juta), biaya penanaman pohon, pengurangan penggunaan kertas dan penghematan energi dari program Earth hour. Kemudian aspek sosial, meliputi penyaluran KUR sejak 2007, total penyaluran KUR per tahun, jumlah pengusaha mikro, kecil dan TKI penerima KUR (orang), total penyaluran KUR dibandingkan target, jumlah kampoeng BNI, skor employee engagement, durasi pelatihan, persentase pegawai terlatih dan jumlah remittance.

Hasil analisa perbandingan dan trend kinerja keuangan pada PT. BNI, Tbk dari aspek ekonomi, dimana indikator jumlah akun consumer funding dan lending (termasuk kartu kredit), dividen, penyaluran program kemitraan dan penyaluran bina lingkungan mengalami peningkatan. Namun sebaliknya jumlah Kantor bank dalam negeri, Kantor cabang luar negri, jumlah pinjaman, jumlah pendapatan, laba tahun berjalan mengalami penurunan. Kemudian aspek lingkungan, dimana indikator penggunaan air, penggunaan listrik, jumlah hutan/taman Kota BNI, luas hutan/taman Kota BNI, biaya penanaman pohon, pengurangan penggunaan kertas dan penghematan energi dari program Earth hour mengalami peningkatan. Namun sebaliknya jumlah total pohon yang ditanam (juta) mengalami penurunan. Selanjutnya aspek sosial, meliputi indikator penyaluran KUR sejak 2007, total penyaluran KUR per tahun, jumlah pengusaha mikro, kecil dan TKI penerima KUR (orang), total penyaluran KUR dibandingkan target, skor employee engagement, persentase pegawai terlatih mengalami penurunan. Sedangkan indikator sosial yang mengalami peningkatan adalah jumlah remittance.
\end{abstract}

Kata Kunci : Keuangan berkelanjutan, Perbandingan, Trend, Bank

\section{PENDAHULUAN}

\section{Latar belakang}

Dalam dua dekade terakhir, pembangunan yang semata-mata menargetkan pertumbuhan ekonomi telah mendapat banyak sorotan, terutama dengan makin maraknya isu penurunan kualitas lingkungan, isu kesenjangan sosial yang makin melebar dan isu perubahan iklim 
dengan segala implikasinya. Dampakdampak negatif yang ditimbulkan dari proses pembangunan ekonomi mendorong dicetuskannya pembangunan berkelanjutan yang mengedepankan keselarasan aspek ekonomi, aspek lingkungan, dan aspek social (OJK, Desember 2014).

Oleh sebab itu negara-negara yang tergabung dalam G20 termasuk di-dalamnya Indonesia mempunyai komitmen mencapai perkembangan ekonomi berkelanjutan (sustainable economic development).

Otoritas Jasa Keuangan (OJK), telah meluncurkan program kinerja keuangan berkelanjutan (Sustainable Finance Roadmap) pada bulan Desember 2014. Roadmap keuangan berkelanjutan tersebut mencakup sektor keuangan, termasuk perbankan, pasar modal, dan lembaga keuangan non-bank (asuransi, leasing, dan dana pensiun) untuk berkontribusi pada komitmen nasional untuk mengatasi perubahan iklim dan mendukung transisi menuju ekonomi rendah karbon yang kompetitif. Payung kebijakan saat ini sedang dirancang untuk memberikan panduan praktis tentang bagaimana menggabungkan keseluruhan sistem keuangan di Indonesia. (Input Paper for the G20 Green Finance Study Group)

OJK dalam tentunya memiliki peran untuk mensukseskan komitmen tersebut melalui program keuangan ber-kelanjutan (sustainable finance). Program ini dilakukan melalui kerjasama ber-bagai pihak sehingga tercipta dukungan pembiayaan kepada industri yang menerapkan prinsip keuangan berkelanjutan. Program keuangan ber-kelanjutan tidak hanya berupaya untuk meningkatkan porsi pembiayaan namun juga untuk meningkatkan daya tahan dan daya saing lembaga jasa keuangan. Arah pengembangan untuk peningkatan daya tahan dan daya saing didasari atas pemikiran bahwasanya sustainable finance merupakan sebuah tantangan dan peluang baru dimana Lembaga Jasa Keuangan (LJK) dapat memanfaatkan untuk tumbuh dan berkembang dengan lebih stabil. Selanjutnya untuk mencapai hal tersebut melalui tahapan tahapan yang sistematis, OJK bekerjasama dengan beberapa lembaga terkait telah menyusun Roadmap Keuangan Berkelanjutan. 
Roadmap ini bertujuan untuk menjabarkan kondisi yang ingin dicapai terkait keuangan yang berkelanjutan di Indonesia dalam jangka menengah (2015-2019) dan panjang (2015-2024) bagi industri jasa keuangan yang berada di bawah pengawasan OJK serta untuk menentukan dan menyusun tonggak perbaikan terkait keuangan berkelanjutan. Roadmap ini akan menjadi acuan bagi OJK dan pelaku industri jasa keuangan serta pihakpihak lain yang memiliki kepentingan untuk mendukung pembangunan berkelanjutan terutama pemerintah, pelaku industri maupun lembaga internasional.

Roadmap ini berisi paparan rencana kerja program keuangan berkelanjutan untuk industri jasa keuangan yang berada di bawah otoritas OJK, yaitu perbankan, pasar modal dan IKNB. Roadmap keuangan berkelanjutan ini akan menjadi bagian dari Master Plan Sektor Jasa Keuangan Indonesia (MPSJKI) serta digunakan sebagai acuan bagi pemangku kepentingan keuangan berkelanjutan lainnya.

Roadmap ini disusun untuk:
1. Menjabarkan kondisi yang ingin dicapai terkait keuangan yang berkelanjutan di Indonesia dalam jangka menengah (5 tahun) dan panjang (10 tahun) untuk lembaga keuangan yang berada di bawah otoritas OJK, yaitu perbankan, pasar modal dan IKNB.

2. Menentukan dan menyusun tonggak perbaikan terkait keuangan berkelanjutan.

Sebanyak delapan bank menjadi peserta pilot project sustainable bank dalam Roadmap Keuangan Berkelanjutan Otoritas Jasa Keuangan (OJK) yang dicanangkan pada Desember 2014. Delapan bank pesertapilot project sustainable bank tersebut antara lain Bank Mandiri, Bank Rakyat Indonesia (BRI), Bank Negara Indonesia (BNI), Bank Central Asia (BCA), Bank ArthaGraha, BPD Jabar-Banten (BJB), Bank Muamalat, dan Bank BRI Syariah. (http://infobanknews.com)

Bank Negara Indonesia atau BNI merupakan sebuah lembaga atau institusi yang dimiliki oleh pemerintah Indonesia dan sebagai perusahaan BUMN yang juga mengikuti program 
keuangan berkelanjutan yang diselenggarakan oleh OJK. Bank Negara Indonesia (BNI) adalah bank komersial tertua dalam sejarah Republik Indonesia. Bank ini didirikan pada tanggal 5 Juli tahun 1946.

Pada tanggal 19 September 2017, adanya penyelenggaran oleh OJK, Kementrian BUMN, BI, Direktorat Jenderal Pajak, Komite Nasional Kebijakan Governance dan IAI, dimana PT. BNI, Tbk menjadi juara 1 Annual Report Award Kategori BUMN Keuangan Listed. Berdasarkan pertimbangan tersebut penulis tertarik meneliti PT. BNI, Tbk dalam menjalankan program kerja keuangan berkelanjutan yang dapat dalam laporan keuangan berkelanjutan (sustainable financial report).

\section{Perumusan Masalah}

Berdasarkan latar belakang yang telah diuraikan diatas, maka rumusan masalah yang akan diuji lebih lanjut dalam penelitian ini adalah:

1. Bagaimana implementasi kinerja keuangan berkelanjutan pada PT. BNI, Tbk jika dilihat dari aspek ekonomi, aspek lingkungan dan aspek sosial pada periode 20152017 ?

2. Bagimana perbandingan dan trend kinerja keuangan berkelanjutan pada PT. BNI, Tbk jika dilihat dari aspek ekonomi, aspek lingkungan dan aspek sosial pada periode 2015-2017?

\section{Pembatasan Masalah}

Pembatasan masalah penelitian ini adalah:

1) Dalam lingkup penelitian ini penulis hanya meneliti implementasi kinerja keuangan keberlanjutan (sustainable finance) dari aspek kinerja keuangan, kinerja lingkungan, dan kinerja sosial dari PT. BNI, Tbk.

2) Tahun evaluasi implementasi kinerja keuangan keberlanjutan yaitu laporan tahun 2015 - 2017.

\section{Tujuan Penelitian}

Berdasarkan rumusan masalah yang disampaikan diatas maka tujuan penelitian ini adalah untuk:

1. Untuk mengetahui implementasi kinerja keuangan berkelanjutan pada PT. BNI, Tbk jika dilihat aspek ekonomi, aspek lingkungan 
dan aspek sosial periode tahun 2015-2017?

2. Untuk meneliti dan mengetahui perbandingan dan trend kinerja keuangan pada PT. BNI, Tbk jika dilihat dari aspek ekonomi, aspek lingkungan dan aspek sosial periode tahun 2015-2017?

\section{TINJAUAN PUSTAKA}

\section{Tujuan dan Prinsip Keuangan Ber-}

\section{kelanjutan di Indonesia}

Keuangan berkelanjutan di Indonesia didefinisikan sebagai dukungan menyeluruh dari industri jasa keuangan untuk pertumbuhan berkelanjutan yang dihasilkan dari keselarasan antara kepentingan ekonomi, sosial, dan lingkungan. Keuangan berkelanjutan terdiri dari dimensi:

1. Mencapai keunggulan industri, sosial dan ekonomi dalam rangka mengurangi ancaman pemanasan global dan pencegahan terhadap permasalahan lingkungan dan sosial lainnya;

2. Memiliki tujuan untuk terjadinya pergeseran target menuju ekonomi rendah karbon yang kompetitif;
3. Secara strategis mempromosikan investasi ramah lingkungan di berbagai sektor usaha/ekonomi; dan

4. Mendukung prinsip-prinsip pembangunan Indonesia sebagaimana tercantum dalam RPJM, yaitu 4P (pro-growth, projobs, pro-poor,dan proenvironment).

\section{Tujuan dan Prinsip Keuangan}

\section{Berkelanjutan}

Tujuan program keuangan berkelanjutan di Indonesia adalah untuk:

1. Meningkatkan daya tahan dan daya saing LJK sehingga mampu tumbuh dan berkembang secara berkesinambungan. Daya tahan dikaitkan dengan kemampuan manajemen risiko yang lebih baik, sementara daya saing dikaitkan dengan kemampuan LJK untuk melakukan inovasi produk/layanan lingkungan yang ramah lingkungan.

2. Menyediakan sumber pendanaan yang dibutuhkan masyarakat mengacu kepada RPJP dan RPJM yang bercirikan pro-growth, pro- 
job, pro-poor, dan pro-

environment.

3. Berkontribusi pada komitmen nasional atas permasalahan pemanasan global (global warming) melalui aktivitas bisnis yang bersifat pencegahan/mitigasi maupun adaptasi atas perubahan iklim menuju ekonomi rendah karbon yang kompetitif.

Prinsip-prinsip program keuangan berkelanjutan di Indonesia mencakup:

\section{Prinsip Pengelolaan Risiko yang} mengintegrasikan aspek perlindungan lingkungan dan sosial dalam manajemen risiko LJK guna menghindari, mencegah dan meminimalisir dampak negatif yang timbul serta mendorong peningkatan kemanfaatan kegiatan pendanaan dan operasional LJK.

\section{Prinsip Pengembangan Sektor} Ekonomi Prioritas berkelanjutan yang bersifat inklusif dengan meningkatkan kegiatan pendanaan terutama pada sektor industri, energi, pertanian (dalam arti luas), infrastruktur dan UMKM dengan menyeimbangkan aspek ekonomi, lingkungan dan sosial; serta menyediakan layanan keuangan kepada komunitas yang umumnya memiliki keterbatasan atau tidak memiliki akses ke layanan keuangan di sektor formal.

\section{Prinsip Tata Kelola Lingkungan} dan Sosial dan Pelaporan dengan menyelenggarakan praktek-praktek tata kelola lingkungan dan sosial yang kokoh dan transparan di dalam kegiatan operasional LJK dan terhadap praktek-praktek tata kelola lingkungan dan sosial yang diselenggarakan oleh nasabahnasabah LJK; serta secara berkala melaporkan kemajuan LJK dalam menerapkan prinsip-prinsip keuangan berkelanjutan ini kepada masyarakat.

\section{Prinsip Peningkatan Kapasitas} dan Kemitraan Kolaboratif dengan mengembangkan kapasitas sumber daya manusia, teknologi informasi dan proses operasional dari masing-masing LJK terkait penerapan prinsipprinsip keuangan berkelanjutan; serta menjalin kerjasama antar 
LJK, regulator, pemerintah dan memanfaatkan kemitraan dengan lembaga-lembaga domestic maupun internasional guna mendorong kemajuan keuangan berkelanjutan.

\section{Rencana Kerja Strategis Dan} Penguatan Keuangan Berkelanjutan

Rencana kerja strategis keuangan berkelanjutan meliputi (3) tiga area yang mencakup:

1. Peningkatan supply pendanaan ramah lingkungan.

2. Peningkatan demand bagi produk keuangan ramah lingkungan.

3. Peningkatan pengawasan dan koordinasi implementasi keuangan berkelanjutan.

Fokus aktivitas di atas diterapkan secara bertahap dalam Jangka Menengah dan Jangka Panjang, dengan uraian sebagai berikut:

\section{Jangka Menengah (2015-2019),} kegiatan penguatan keuangan berkelanjutan difokuskan pada kerangka dasar pengaturan dan sistem pelaporan, peningkatan pemahaman, pengetahuan serta kompetensi sumber daya manusia pelaku industri jasa keuangan, pemberian insentif serta koordinasi dengan instansi terkait.

\section{Jangka panjang (2020-2024),} kegiatan difokuskan pada integrasi manajemen risiko, tata kelola perusahaan, penilaian tingkat kesehatan bank dan pembangunan sistem informasi terpadu keuangan berkelanjutan. Beberapa kondisi terkait penerapan keuangan berkelanjutan yang ingin dicapai berdasarkan jangka menengah dan jangka panjang tersebut diatas adalah sebagai berikut:

A. Dalam Jangka Menengah (2015-2019) diharapkan kerangka dasar pengaturan dan sistem pelaporan telah terbangun dan berjalan dengan baik. Pemahaman, pengetahuan serta kompetensi sumberdaya manusia pelaku industri jasa keuangan terkait keuangan berkelanjutan juga diharapkan telah meningkat serta pemberian insentif serta koordinasi dengan instansi terkait telah terjalin secara baik dan dilakukan secara berkala. Juga diharapkan telah 
terbentuknya sistem untuk

memonitor

peningkatan

volume pendanaan di sektor

ekonomi prioritas yang

menerapkan prinsip-prinsip

keuangan berkelanjutan.

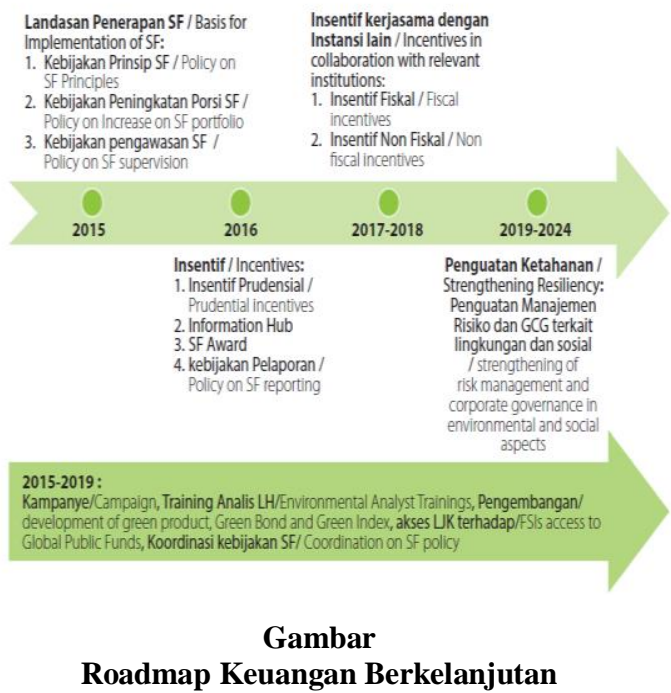

Dalam Jangka Panjang (2020-

2024), IJK diharapkan telah mengintegrasikan aspek lingkungan dan sosial dalam manajemen risiko dan tata kelola perusahaan serta melaporkan kemajuan penerapan keuangan berkelanjutan secara berkala kepada masyarakat. Sistem informasi terpadu dengan institusi terkait untuk mendukung penerapan keuangan berkelanjutan telah terbentuk dan berjalan dengan baik. Diharapkan juga bahwa program keuangan berkelanjutan ini dapat meningkatkan kontribusi terhadap target penurunan emisi gas rumah kaca nasional.

\section{Analisis Perbandingan}

Menurut Harahap (2010:227), analisis perbandingan adalah teknik analisis laporan keuangan yang dilakukan dengan cara menyajikan laporan keuangan secara horizontal dan membandingkan antara satu dengan yang lain, dengan menunjukkan informasi keuangan atau data lainnya baik dalam rupiah atau dalam unit. Teknik perbandingan ini juga dapat menunjukkan kenaikan dan penurunan dalam rupiah atau unit dan juga dalam persentase atau perbandingan dalam bentuk angka perbandingan atau rasio. Tujuan analisis perbandingan ini adalah untuk mengetahui perubahan-perubahan berupa kenaikan atau penurunan akunakun laporan keuangan atau data lainnya dalam dua atau lebih periode yang dibandingkan.

Menurut Kasmir (2012:104), rasio keuangan merupakan kegiatan membandingkan angka-angka yang ada dalam laporan keuangan dengan cara membagi satu angka dengan angka lainnya. Perbandingan dapat 
dilakukan antara satu komponen dengan komponen yang ada di antara laporan keuangan. Kemudian angka yang diperbandingkan dapat berupa angka-angka dalam satu periode maupun beberapa periode.

Menurut Harahap (2010:227228), dalam melakukan analisis laporan keuangan teknik perbandingan ini, kita dapat membandingkannya dengan angka-angka laporan keuangan tahun lalu, angka laporan keuangan perusahaan sejenis, rasio rata-rata industri, dan rasio normatif sebagai standar perbandingan (yardstick).

Perbandingan antarpos laporan keuangan dapat dilakukan melalui:

1. Perbandingan dalam dua atau beberapa tahun (horisontal) misalnya laporan keuangan tahun 2012, dibandingkan dengan laporan keuangan tahun 2013. Perbandingan antara tahun 2012, 2013, 2014, dan seterusnya.

2. Perbandingan dengan perusahaan yang dianggap terbaik.

3. Perbandingan dengan angkaangka standar industri yang berlaku (industrial norm). Di Indonesia standar ini belum ada tetapi di USA beberapa perusahaan mengkhususkan diri mensupply informasi rasio ini misalnya Moody's, Standar \& Poor dan lain-lain.

4. Perbandingan dengan budget (anggaran).

5. Perbandingan dengan bagian, divisi, atau seksi yang ada dalam suatu perusahaan.

\section{Analisis Trend Dalam Presentase}

Menurut Sunyoto (2012: 140), besar kecilnya perubahan tergantung dari faktor-faktor yang mempengaruhinya dan rangkaian waktu (time series) dari variabel tertentu, sehingga dapat didefinisikan bahwa Analisis Trend adalah suatu analisis yang menggambarkan atau menunjukkan perubahan rata-rata suatu variabel tertentu dari waktu ke waktu. Perubahan rata-rata sautu variabel yang mengalami kecenderungan penurunan nilai disebut trend negatif. Perubahan ratarata satu variabel yang mengalami peningkatan nilai disebut trend posistif.

Manfaat analisis trend adalah untuk memproyeksikan nilai suatu variabel pada saat tertentu. Untuk 
mengukur proyeksi suatu nilai variabel dengan menggunakan analisis trend ada beberapa cara yaitu:

- Trend Linier (trend garis lurus), ada tiga metode yaitu metode tangan bebas, metode setengah rata-rata dan metode kuadrat terkecil.

- Trend Non Linier (trend garis lengkung), ada dua trend yaitu trend parabola dan trend eksponential dan logaritma.

\section{METODE PENELITIAN}

Metode penelitian adalah suatu cara atau teknis yang digunakan dalam sebuah penelitian. Metode yang digunakan dalam penelitian ini adalah deskriptif kuantitatif. Variabel tersebut dibahas dan diuraikan. secara kuantitatif yang disusun secara sistematis untuk menilai evaluasi perbandingan dan trend kinerja keuangan berkelanjutan perusahaan antara lain dari aspek ekonomi, aspek aspek lingkungan dan aspek sosial pada PT. BNI, Tbk selama periode tahun 2015 - 2017. Tata cara penilaian dilihat dari besar kecilnya hasil perhitungan persentase perubahan dari masing-masing aspek keuangan berkelanjutan.

\section{ANALISIS DAN PEMBAHASAN}

Aspek Ekonomi

Penilaian aspek ekonomi meliputi jumlah kantor bank dalam negeri, kantor cabang luar negeri, jumlah akun consumer funding dan lending (termasuk kartu kredit), jumlah pinjaman, jumlah pendapatan, laba tahun berjalan, dividen, penyaluran program kemitraan dan penyaluran bina lingkungan.

Pada tabel 1 dapat dilihat bahwa jumlah akun consumer funding dan lending (termasuk kartu kredit), dividen, penyaluran program kemitraan dan penyaluran bina lingkungan mengalami peningkatan. Namun sebaliknya jumlah Kantor bank dalam negeri, Kantor cabang luar negri, jumlah pinjaman, jumlah pendapatan, laba tahun berjalan mengalami penurunan. Untuk persentase peningkatan terbesar pada aspek ekonomi jika dibandingkan perubahan tahun 2015-2016 dengan tahun 2016-2017 yaitu penyaluran program kemitraan yaitu sebesar $179.41 \%$. 
Tabel

Keuangan Berkelanjutan Aspek Ekonomi PT. BNI, Tbk

\begin{tabular}{|c|c|c|c|c|c|c|c|}
\hline \multirow{2}{*}{ Indikator } & \multicolumn{3}{|c|}{ Tahun } & \multicolumn{3}{|c|}{ Tahun } & \multirow{2}{*}{ Ket } \\
\hline & 2015 & 2016 & $\% \Delta$ & 2016 & 2017 & $\% \Delta$ & \\
\hline Jumlah kantor bank dalam negeri & 1826 & 1990 & 8.06 & 1990 & 2150 & 8.04 & Menurun \\
\hline Kantor Cabang luar negeri & 7 & 8 & 14.28 & 8 & 8 & 0 & Menurun \\
\hline $\begin{array}{l}\text { Jumlah akun consumer funding \& } \\
\text { lending (termasuk kartu kredit) }\end{array}$ & 18.5 & 22.3 & 20.54 & 22.3 & 33.5 & 50.22 & Meningkat \\
\hline Jumlah pinjaman & 326.105 & 393.275 & 20.59 & 393.275 & 441.314 & 12.21 & Menurun \\
\hline Jumlah pendapatan & 49.1 & 59.30 & 20.77 & 59.30 & 66.6 & 12.31 & Menurun \\
\hline Laba Tahun berjalan & 9.14 & 11.41 & 24.83 & 11.41 & 13.77 & 20.68 & Menurun \\
\hline Dividen & 2.7 & 2.3 & 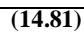 & 2.3 & 3.9 & 69.56 & Meningkat \\
\hline Penyaluran program kemitraan & 23.76 & 24.98 & 5.13 & 24.98 & 71.08 & 184.54 & Meningkat \\
\hline Penyaluran Bina Lingkungan & 77.04 & 62.75 & (18.54) & 62.75 & 107.76 & 71.72 & Meningkat \\
\hline
\end{tabular}

Secara garis besar dapat dilihat pada grafik trend aspek ekonomi dapat dilihat pada Gambar dibawah berikut ini:

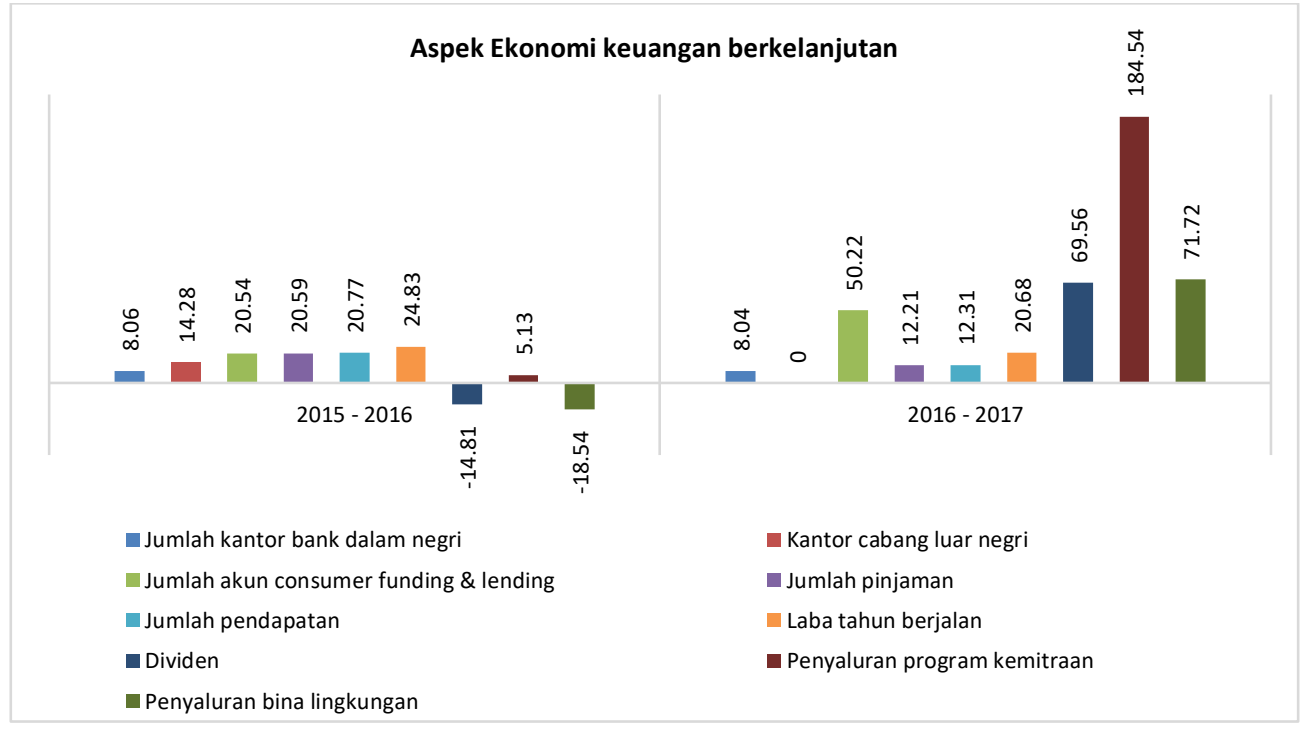

Gambar

Grafik Trend Aspek Ekonomi Keuangan Berkelanjutan

\section{Aspek Lingkungan}

Keuangan berkelanjutan juga dilihat dari aspek lingkungan yakni penggunaan listrik, air, jumlah hutan/taman kota BNI, luas hutan/taman kota BNI, jumlah total pohon yang ditanam (juta), biaya penanaman pohon, pengurangan penggunaan kertas dan penghematan energi dari program Earth hour.

Pada tabel 2 dapat dilihat penggunaan air, penggunaan listrik, 
jumlah hutan/taman kota BNI, luas hutan/taman kota BNI, biaya penanaman pohon, pengurangan penggunaan kertas dan penghematan energi dari program Earth hour mengalami peningkatan. Namun sebaliknya jumlah total pohon yang ditanam (juta) mengalami penurunan. Untuk persentase peningkatan terbesar pada aspek lingkungan jika dibandingkan perubahan tahun 20152016 dengan tahun 2016-2017 yaitu penghematan energi dari program Earth hour yaitu sebesar $21.94 \%$
Kemudian persentase penurunan terbesar aspek lingkungan yaitu jumlah total pohon yang ditanam (juta), dimana sebelumnnya $402.46 \%$ hanya menjadi 012\%. Dengan demikian secara keseluruhan aspek ekonomi PT. BNI, Tbk harus tetap mempertahankan indikator aspek lingkungan yang meningkat, namun masih perlu meningkatkan indikator kinerja aspek ekonomi yang masih kurang guna mendukung penguatan keuangan berkelanjutan.

Tabel

Keuangan Berkelanjutan Aspek Lingkungan PT. BNI, Tbk

\begin{tabular}{|c|c|c|c|c|c|c|c|}
\hline \multirow[t]{2}{*}{ Indikator } & \multicolumn{3}{|c|}{ Tahun } & \multicolumn{3}{|c|}{ Tahun } & \multirow{2}{*}{ Ket } \\
\hline & 2015 & 2016 & $\% \Delta$ & 2016 & 2017 & $\% \Delta$ & \\
\hline Listrik & $\begin{array}{c}18.221 .82 \\
0\end{array}$ & $\begin{array}{c}18.705 .21 \\
7\end{array}$ & $(2.65)$ & $\begin{array}{c}18.705 .21 \\
7\end{array}$ & $\begin{array}{c}18.220 .92 \\
0\end{array}$ & 2.58 & Meningkat \\
\hline Air & 154.794 & 160.285 & (3.54) & 160.285 & 147.318 & 8.08 & Meningkat \\
\hline $\begin{array}{l}\text { Jumlah hutan/taman kota } \\
\text { BNI }\end{array}$ & 13 & 13 & 0 & 13 & 15 & 15.38 & Meningkat \\
\hline $\begin{array}{l}\text { Luas hutan/taman kota } \\
\text { BNI (ribu m2) }\end{array}$ & 771.2 & 771.2 & $\mathbf{0}$ & 771.2 & 811.4 & 5.21 & Meningkat \\
\hline $\begin{array}{l}\text { Jumlah total Pohon } \\
\text { ditanam (juta) }\end{array}$ & 1.62 & 8.14 & 402.46 & 8.14 & 8.15 & 0.12 & Menurun \\
\hline $\begin{array}{l}\text { Biaya Penanaman pohon } \\
\text { (miliar rupiah) }\end{array}$ & 31.06 & 31.06 & $\mathbf{0}$ & 31.06 & 31.23 & 0.54 & Meningkat \\
\hline $\begin{array}{l}\text { Pengurangan Penggunaan } \\
\text { Kertas (ton) }\end{array}$ & 2.085 & 2.085 & $\mathbf{0}$ & 2.085 & 2.155 & 3.35 & Meningkat \\
\hline $\begin{array}{l}\text { Penghematan energi dari } \\
\text { program Earth Hour } \\
(\mathrm{MWh})\end{array}$ & 6.058 .13 & $6.058,13$ & $\mathbf{0}$ & $6.058,13$ & $7.387,67$ & 21.94 & Meningkat \\
\hline
\end{tabular}

Secara garis besar dapat dilihat pada grafik trend aspek lingkungan dapat dilihat pada Gambar dibawah berikut ini: 


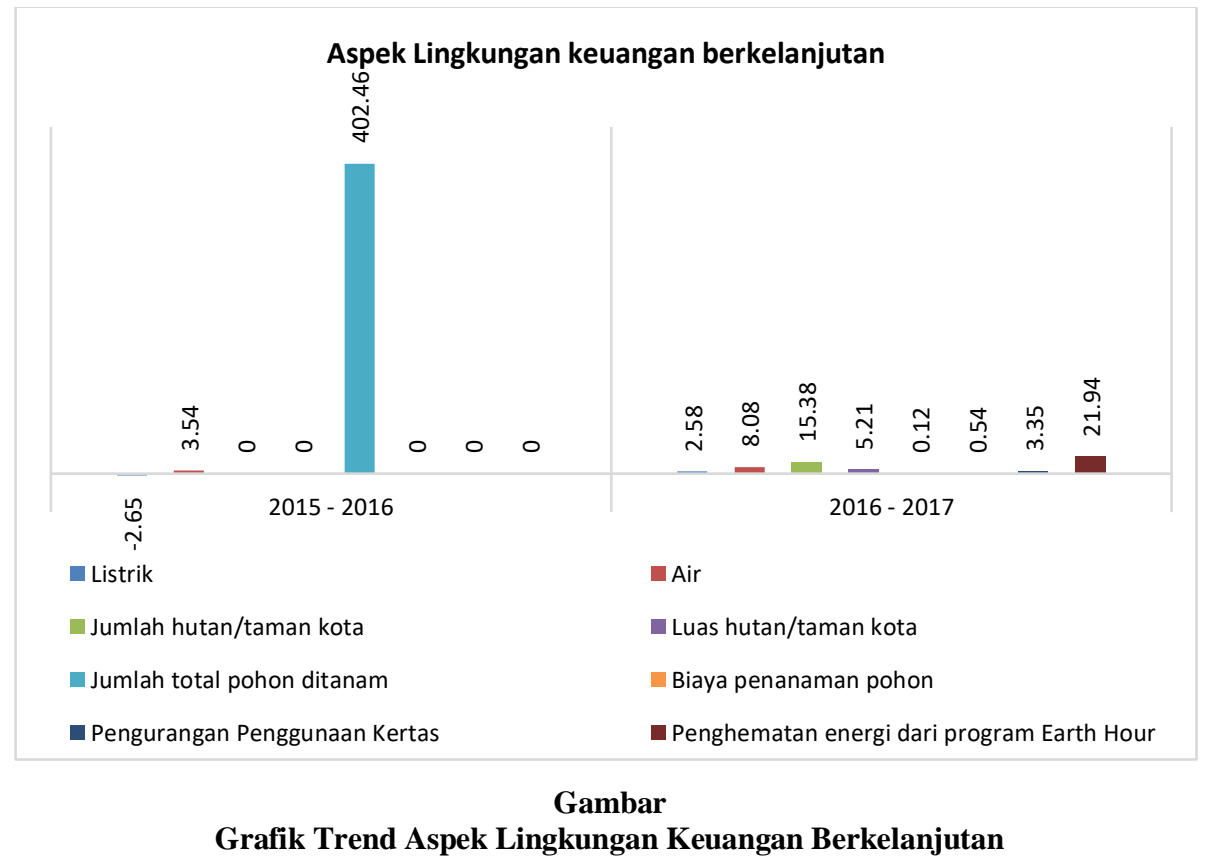

\section{Aspek Sosial}

Penilaian aspek sosial meliputi penyaluran KUR sejak 2007, total penyaluran KUR per tahun, jumlah pengusaha mikro, kecil dan TKI penerima KUR (orang), total penyaluran KUR dibandingkan target, jumlah kampoeng BNI, skor employee engagement, durasi pelatihan, persentase pegawai terlatih dan jumlah remittance.

Pada tabel 3 dapat dilihat penyaluran KUR sejak 2007, total penyaluran KUR per tahun, jumlah pengusaha mikro, kecil dan TKI penerima KUR (orang), total penyaluran KUR dibandingkan target, skor employee engagement, persentase pegawai terlatih mengalami penurunan. Sedangkan indikator sosial yang mengalami peningkatan adalah jumlah remittance yaitu sebesar 25.52\%. Untuk jumlah kampoeng BNI dan dan durasi pelatihan tidak mengalami perubahan atau tetap. Sedangkan untuk persentase penurunan terbesar pada aspek sosial jika dibandingkan perubahan tahun 2015-2016 dengan tahun 2016-2017 yaitu jumlah pengusaha mikro, kecil dan TKI penerima KUR. Penurunan jumlah pengusaha mikro, kecil dan TKI penerima KUR tahun 2016 2017 totalnya sebesar 213.729 orang, sehingga sangat berdampak pada persentase perubahan indikator 
tersebut. Dengan demikian secara keseluruhan aspek sosial PT. BNI, Tbk masih perlu peningkatan. Oleh sebab itu harus ada upaya-upaya untuk meningkatkan indikator kinerja aspek sosial yang masih kurang guna mendukung penguatan keuangan berkelanjutan.

Tabel

Keuangan Berkelanjutan Aspek Sosial PT. BNI, Tbk

\begin{tabular}{|l|c|c|c|c|c|c|c|}
\hline \multirow{2}{*}{ Keterangan } & \multicolumn{3}{|c|}{ Tahun } & \multicolumn{3}{c|}{ Tahun } & \multirow{2}{*}{ Ket } \\
\cline { 2 - 7 } & $\mathbf{2 0 1 5}$ & $\mathbf{2 0 1 6}$ & $\mathbf{9} \Delta$ & $\mathbf{2 0 1 6}$ & $\mathbf{2 0 1 7}$ & \% $\Delta$ & Menurun \\
\hline $\begin{array}{l}\text { Penyaluran KUR sejak 2007 (miliar } \\
\text { rupiah) }\end{array}$ & 18.725 & 29.050 & $\mathbf{5 5 . 1 4}$ & 29.050 & 38.795 & $\mathbf{3 3 . 5 4}$ & \\
\hline Total penyaluran KUR per tahun (miliar) & 3.044 & 10.325 & $\mathbf{2 3 9 . 1 9}$ & 10.325 & 9.745 & $\mathbf{( 5 . 6 1 )}$ & Menurun \\
\hline $\begin{array}{l}\text { Jumlah pengusaha mikro, Kecil dan TKI } \\
\text { Penerima KUR (orang) }\end{array}$ & 12.236 & 275.335 & $\mathbf{2 1 5 0 . 2}$ & 275.335 & 61.606 & $\mathbf{( 7 7 . 6 2 )}$ & Menurun \\
\hline $\begin{array}{l}\text { Total Penyaluran KUR dibandingkan } \\
\text { target (\%) }\end{array}$ & 86 & 86 & $\mathbf{0}$ & 86 & 81.1 & $\mathbf{( 5 . 6 9 )}$ & Menurun \\
\hline Jumlah Kampoeng BNI & & & & & & & 0 \\
\hline Skor Employee Engagement (\%) & 55.22 & 55.22 & $\mathbf{0}$ & 55.22 & 51.36 & $\mathbf{( 6 . 9 9 )}$ & Menurun \\
\hline Durasi Pelatihan (juta jam) & 1.8 & 1.7 & $\mathbf{( 5 . 5 5 )}$ & 1.7 & 1.7 & $\mathbf{0}$ & Tetap \\
\hline Persentase Pegawai terlatih (\%) & 96 & 99.76 & $\mathbf{3 . 9 1}$ & 99.76 & 98.98 & $\mathbf{( 0 . 0 7 )}$ & Menurun \\
\hline Jumlah remittance & 133.100 & 133.100 & $\mathbf{0}$ & 133.100 & 167.073 & $\mathbf{2 5 . 5 2}$ & Meningkat \\
\hline
\end{tabular}

Secara garis besar dapat dilihat pada grafik trend aspek sosial dapat dilihat pada Gambar dibawah berikut ini:

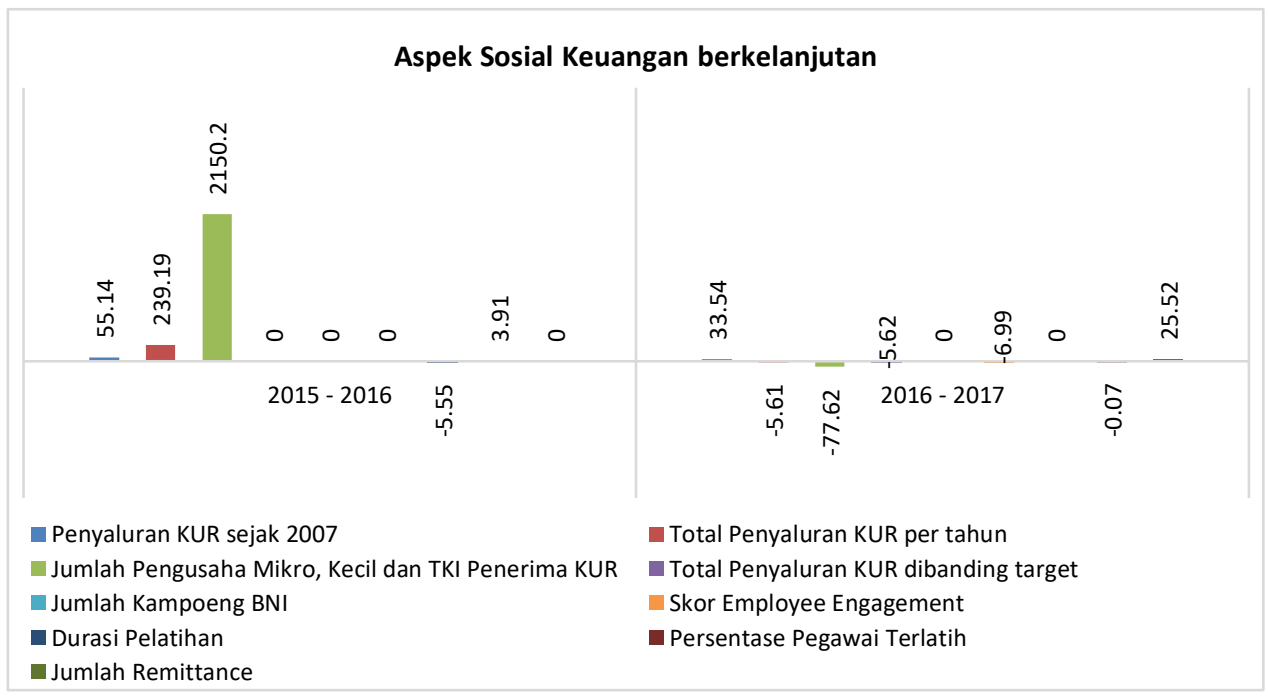

Gambar

Grafik Trend Aspek Sosial Keuangan Berkelanjutan 
Pembangunan keuangan berkelanjutan membutuhkan upaya pengaturan diri dan tindakan sukarela oleh PT. BNI, Tbk, melalui tanggung jawab sosial perusahaan dan tata kelola perusahaan, menangani insentif yang tidak sejajar, asimetri informasi, inovasi keuangan dan tingkat risiko. Dampak dari kelemahan ini di sektor keuangan, yang terungkap selama krisis keuangan, sama-sama menimbulkan potensi risiko sosial dan lingkungan yang sangat besar. Oleh sebab itu indikator pelaporan keberlanjutan dan kinerja dinilai untuk memverifikasi apakah bukti tersebut merupakan bukti hasil keberlanjutan dari aspek ekonomi, lingkungan dan sosial.

\section{KESIMPULAN DAN SARAN}

\section{Kesimpulan}

1. Kinerja keuangan pada PT. BNI, Tbk jika dilihat aspek ekonomi, aspek lingkungan dan aspek sosial periode tahun 2015-2017 sebagai berikut:

a. Aspek ekonomi, meliputi jumlah kantor bank dalam negeri, kantor cabang luar negeri, jumlah akun consumer funding dan lending (termasuk kartu kredit), jumlah pinjaman, jumlah pendapatan, laba tahun berjalan, dividen, penyaluran program kemitraan dan penyaluran bina lingkungan. Persentase peningkatan terbesar tahun 2015-2016 dengan tahun 2016-2017 yaitu penyaluran program kemitraan yaitu sebesar $179.41 \%$ Kemudian persentase penurunan terbesar aspek ekonomi yaitu kantor cabang luar negri (14.28\%).

b. Aspek lingkungan, meliputi penggunaan listrik, air, jumlah hutan/taman Kota BNI, luas hutan/taman Kota BNI, jumlah total pohon yang ditanam (juta), biaya penanaman pohon, pengurangan penggunaan kertas dan penghematan energi dari program Earth hour. Persentase penurunan terbesar aspek lingkungan yaitu jumlah total pohon yang ditanam (juta), dimana sebelumnnya $402.46 \%$ hanya menjadi $012 \%$. 
c. Aspek sosial, meliputi penyaluran KUR sejak 2007, total penyaluran KUR per tahun, jumlah pengusaha mikro, kecil dan TKI penerima KUR (orang), total penyaluran KUR dibandingkan target, jumlah kampoeng BNI, skor employee engagement, durasi pelatihan, persentase pegawai terlatih dan jumlah remittance. Penurunan jumlah pengusaha mikro, kecil dan TKI penerima KUR tahun 2016 - 2017 totalnya sebesar 213.729 orang, sehingga sangat berdampak pada persentase perubahan indikator tersebut.

2. Hasil analisa perbandingan dan trend kinerja keuangan pada PT. BNI, Tbk jika dilihat dari aspek ekonomi, aspek lingkungan dan aspek sosial periode tahun 20152017, antara lain sebagai berikut:

a. Aspek ekonomi, dimana indikator jumlah akun consumer funding dan lending (termasuk kartu kredit), dividen, penyaluran program kemitraan dan penyaluran bina lingkungan mengalami peningkatan. Namun sebaliknya jumlah Kantor bank dalam negeri, Kantor cabang luar negri, jumlah pinjaman, jumlah pendapatan, laba tahun berjalan mengalami penurunan.

b. Aspek lingkungan, dimana indikator penggunaan air, penggunaan listrik, jumlah hutan/taman Kota BNI, luas hutan/taman Kota BNI, biaya penanaman pohon, pengurangan penggunaan kertas dan penghematan energi dari program Earth hour mengalami peningkatan. Namun sebaliknya jumlah total pohon yang ditanam (juta) mengalami penurunan.

c. Aspek sosial, meliputi indikator penyaluran KUR sejak 2007, total penyaluran KUR per tahun, jumlah pengusaha mikro, kecil dan TKI penerima KUR (orang), total penyaluran KUR dibandingkan target, skor 
employee engagement,

persentase pegawai terlatih mengalami penurunan.

Sedangkan indikator sosial yang mengalami peningkatan adalah jumlah remittance.

\section{Rekomendasi}

1. Hal paling kritis yaitu jika PT. BNI, Tbk serius dengan komitmen mereka terhadap kebijakan dan pelaporan keberlanjutan. PT. BNI, Tbk harus menunjukkan hal ini dalam pemerintahan dan kepemimpinan mereka dengan membentuk dewan dan komite eksekutif untuk memulai komitmen dan meninjau kinerjanya, dan dengan memasukkan kinerja dalam komitmen ini di indikator kinerja utama lembaga.

2. Perlunya perbaikan dalam komitmen kebijakan PT. BNI, Tbk terhadap keberlanjutan di sektor keuangan dan investasi. Dimana hal ini secara tidak langsung akan mengubah secara mendasar model bisnis dan praktik bisnis PT. BNI, Tbk menuju keberlanjutan dan keuangan bermanfaat secara sosial dan bermanfaat bagi lingkungan.

3. Pengembangan lebih lanjut dari penelitian ini dapat berguna meliputi: melakukan analisis kualitatif lebih lanjut mengenai komitmen dan pelaporan kebijakan bank-bank di Indonesia, untuk memastikan pendekatan dan kelemahan khas dari berbagai institusi perbankan. Kemudian memperluas sampel untuk mencakup lembaga keuangan besar lainnya untuk melengkapi analisis kuantitatif terhadap kinerja keberlanjutannya dan kemudian melakukan analisis kualitatif serupa.

\section{DAFTAR PUSTAKA}

Clarke, Thomas and Martijn Boersma. 2016. Sustainable finance? A critical analysis of the regulation, policies, strategies, implementation and reporting on sustainability in international finance. Design of Sustainable Financial System. The United Nations Environment Programme (UNEP). International Environment House. Geneva. Switzerland.

Department of banking research and regulation. 2014. Clean energy 
Handbook For financial service institutions. Otoritas Jasa Keuangan (OJK). Jakarta.

Harahap, Sofian Safri, 2010, Analisis Kritis Atas Laporan Keuangan, Jakarta: Rajawali Persada.

Keown, Arthur J, John D Martin J. William Petty, David F. Scott Jr. 2017. Manajemen Keuangan: Prinsip dan Aplikasi. Edisi Kesepuluh. PT. Indeks.

Kasmir 2012, Analisis Laporan Keuangan, Jakarta: Rajawali Pers.

Laporan keberlanjutan PT. BNI Tahun 2013.

Laporan keberlanjutan PT. BNI Tahun 2014.

Laporan keberlanjutan PT. BNI Tahun 2015.

Laporan keberlanjutan PT. BNI Tahun 2016.

Laporan keberlanjutan PT. BNI Tahun 2017.

Sugiyono, 2010. Metode Penelitian Bisnis. Cetakan Kelimabelas. Bandung. Alfabeta.

Sunyoto, D. 2012. Manajemen Sumber Daya Manusia, Yogyakarta: CAPS.

Tim Penyusun Roadmap Keuangan Berkelanjutan. 2014. Roadmap Keuangan Berkelanjutan di
Indonesia (Roadmap for Sustainable Finance in Indonesia). Otoritas Jasa Keuangan (OJK). Jakarta.

Toto Prihadi, 2013. Analisis Laporan Keuangan Teori dan Aplikasi. Cetakan ketiga. Jakarta: PPM.

Ulrich Volz, Simon Zadek, Aditi Maheshwari and Jessica Robinson. 2015. Towards a Sustainable Financial System in Indonesia. The UNEP Inquiry into the Design of a Sustainable Financial System in partnership with The Association for Sustainable and Responsible Investment in Asia (ASrIA) and the International Finance Corporation. International Environment House. Geneva. Switzerland. 